\title{
Study on hearing loss and its relationship with work in pesticide-exposed tobacco growers
}

\author{
Denise Maria Vaz Romano França ${ }^{1}$ \\ https://orcid.org/0000-0002-6660-4902 \\ Diolen Conceição Barros Lobato ${ }^{1}$ \\ https://orcid.org/0000-0002-8500-6940 \\ Elver Andrade Moronte ${ }^{2}$ \\ https://orcid.org/0000-0003-0999-100X \\ Guilherme Souza Cavalcanti de Albuquerque ${ }^{3}$ \\ https://orcid.org/0000-0002-9682-3380 \\ Patricia Arruda Alcarás $\mathbf{s}^{1,4}$ \\ https://orcid.org/0000-0002-7544-412X \\ Claudia Giglio de Oliveira Gonçalves ${ }^{1}$ \\ https://orcid.org/0000-0001-5798-2410 \\ Adriana Bender Moreira de Lacerda ${ }^{1,5}$ \\ https://orcid.org/0000-0001-8316-1392
}

Universidade Tuiuti do Paraná, Programa de Mestrado e Doutorado, Curitiba, Paraná, Brasil

Ministério Público do Trabalho, Curitiba, Paraná, Brasil

Universidade Federal do Paraná, Núcleo de Estudos em Saúde Coletiva, Curitiba, Paraná, Brasil

${ }^{4}$ Universidade do Oeste Paulista, Presidente Prudente, São Paulo, Brasil

${ }^{5}$ Université de Montréal, Montreal,

Québec, Canada

Conflict of interests: Nonexistent

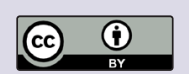

Received on: July 22, 2019

Accepted on: April 6, 2020

Corresponding address:

Adriana Bender Moreira de Lacerda

Rua Sydnei Antonio Rangel Santos, $n^{0} 238$

CEP: 82010-330 - Curitiba, Paraná, Brasil

E-mail: adriana.lacerda@utp.br

\section{ABSTRACT}

The Purpose of this case report is to present four cases of tobacco growers with hearing loss due to occupational exposure to pesticides. A qualitative case study comprising three cases of sensorineural hearing loss with causal nexus (Cases 1, 2 and 4), and one (Case 3) of sensorineural hearing loss compatible with ototoxicity by pesticides, with causal nexus mainly based on minor neuropsychiatric disorders. The sample was composed of rural workers with health problems, in working age, having started working early in life, exposed to various pesticides, including organophosphates. The auditory and neurovegetative symptoms reported were noise discomfort $(n=2)$, speech perception difficulty $(n=3)$, dizziness $(n=2)$, and imbalance $(n=2)$. The pure-tone audiometry revealed a sensorineural hearing loss in one or more high frequencies, and one of the cases presented alteration in the brainstem auditory evoked potentials. There is evidence, in this study, of an association between hearing loss and work in tobacco growers exposed to pesticides, with peripheral auditory damage in four cases, and central damage in one of them. Thus, the need for a complete audiological evaluation of pesticide-exposed populations is highlighted.

Keywords: Damage Assessment; Agrochemicals; Occupational Health; Hearing 


\section{INTRODUCTION}

The main goal of occupational health is to understand and intervene in the relationship between labor and health, to develop the comprehensive health care given to workers. In addition, it aims to promote and protect their health, further health vigilance actions, and assist in work-related health conditions ${ }^{1-3}$.

Intoxication caused by substances present in the working environment is one of the workers' health conditions. In Brazil, case notification of work-related exogenous intoxication, including those caused by pesticides, is mandatory and must be submitted to the sanitary authorities ${ }^{4}$. Notifying noise-induced hearing loss (NIHL) to the sanitary authorities is also compulsory ${ }^{4}$.

Both the Pan American Health Organization (PAHO) and the World Health Organization (WHO) consider a case with suspicion for pesticide intoxication "every individual who, having been exposed to pesticides, presents clinical signs and/or symptoms of intoxication"5. Moreover, even with no clinical signs and/or symptoms of intoxication, cases of people who have been exposed to pesticides and present laboratory alterations compatible with intoxication are also considered suspicious for it 5 .

There is evidence that hearing loss can be related to endogenous pesticide intoxication $n^{6,7}$, which may be considered an early manifestation of chronic intoxication by this chemical agent ${ }^{8}$. For this reason, both basic and complementary audiological assessments contribute to early identifying the intoxication and determine the causal nexus in the pesticide-exposed populations ${ }^{9}$. However, there are few studies demonstrating such evidence ${ }^{10}$.

A study ${ }^{10}$ aimed at researching chronic pesticide intoxication and its relationship with the work process in tobacco growth assessed 46 individuals with a qualitative and quantitative approach. They were surveyed regarding pesticide intoxication signs and symptoms, a lifestyle characterized according to their employment and consumption habits, and their correlation with the current production process. They were submitted to anamnesis with detailed work history, and physical and complementary examinations ${ }^{9}$. The relationship between their condition and pesticide exposure was confirmed in 20 of the 46 adults assessed. The three most common manifestations in chronic intoxication due to occupational exposure to multiple pesticides were: minor psychiatric disorders $(90 \%)$, sensorineural hearing loss (15\%), and organophosphate-induced late polyneuropathy $(10 \%)^{10}$. All the cases were notified to the sanitary authorities and referred for the necessary assistance, according to each situation, at the public health care system (Sistema Único de Saúde - SUS). Each one of them was also given a medical report following the necessary guidance. After the intoxication was confirmed, they were advised to withdraw from pesticide exposure, as their clinical condition could be aggravated $^{10}$.

Given the above, to state the contribution of audiological assessments in determining the causal nexus in chronic pesticide intoxication cases, this case study aimed to present four cases of tobacco growers exposed to pesticides, identified in a previous study ${ }^{10}$, who had a causal nexus between hearing loss and their occupation.

\section{CASE REPORT}

\section{Presentation of Clinical Cases}

This is a case study with a qualitative data analysis. It was approved by the Human and Animal Research Ethics Committee of the Universidade Estadual do Centro Oeste do Paraná, COMEP/UNICENTRO, in Brazil, official letter no. 081/2011, title page no. 413146, and evaluation report no. 023/2011, dated October 17, 2011. The Informed Consent Form was duly signed.

This case study's sample comprised four cases selected due to the occurrence of hearing loss and concomitant causal nexus to pesticide exposure. Three of these cases had sensorineural hearing loss with the causal nexus confirmed (Cases 1,2 and 4), and one (Case 3) with sensorineural hearing loss compatible with pesticide ototoxicity; in this case, the causal nexus was confirmed based mostly on minor neuropsychiatric disorders. These four cases made up the sample of a previous study ${ }^{10}$. However, elements important to determine the causal nexus - e.g., the audiological findings and the aspects considered in decisionmaking - were not previously presented.

In the study of work-related exposures, various aspects were considered, and the criteria were followed according to the Brazilian Federal Council of Medicine Resolution no. 1.940/201011:

- Time of exposure: the investigation of total work exposure in contact with pesticides was relevant.

- Workload and work process: the forms of exposure, aerosol pesticide application (back sprayer, airborne pesticides), contact with the skin or respiratory 
system, and others were considered. Also, the know-how of the activities performed during the workday and the seasons (preparing the sprouts, planting, harvesting, and others).

- Types of pesticides: the chemical products used in the work process were investigated (organophosphates, carbamates, pyrethroids, herbicides, fungicides, and others).

- Type of environment: the environment where the worker performs their duties was visited.

- Use of personal protective equipment (PPE): it was investigated whether they used protective equipment (as boots, coveralls, impermeable gloves and hood, goggles, chemical respirator mask).

- Clinical assessment: the anamnesis - with the detailed description of all symptoms reported, especially the neuropsychiatric ones - was an important element of the study.

The cases were assessed by three physicians and one speech-language-hearing therapist, when the relationship between the health condition and occupational exposure to multiple pesticides were either confirmed or dismissed, following the abovementioned criteria $^{11}$. In the cases requiring specialized assessment, a neurologist was invited to join the team.

\section{RESULTS}

The aspects considered to determine the nexus of the four cases presented in this study were: 1) the data collected in the anamnesis and presented in the characterization of the clinical health condition and assessment of pesticide exposure (Figures 1, 2, 3, and $4)$; 2) the audiological examinations (Figure 5). The epidemiological data in the group's area of exposure were also analyzed, as well as the history of acute intoxications and their seriousness, collected in a previous study $^{10}$. All these aspects are individually detailed in Figures 1 to 5 .

The involvement of a multidisciplinary team and the use of a protocol that considered the social determinants of health ${ }^{9,12}$, were necessary to establish the relationship between the auditory symptoms or alterations and the chronic pesticide intoxications.

\section{Sample Characterization}

To characterize the sample, the data identifying the participants and those related to their work and health conditions are presented in Figures 1, 2, and 3, respectively.

\begin{tabular}{|l|c|c|c|c|}
\hline Identification & Case 1 & Case 2 & Case 3 & Case 4 \\
\hline Age & 47 years & 49 years & 53 years & 39 years \\
\hline Gender & Male & Male & Male & Male \\
\hline Schooling & Unfinished middle school & Unfinished middle school & Unfinished middle school & Unfinished middle school \\
\hline
\end{tabular}

Source: The authors.

Figure 1. Data on pesticide-exposed tobacco growers 


\begin{tabular}{|c|c|c|c|c|}
\hline Work data & Case 1 & Case 2 & Case 3 & Case 4 \\
\hline Type of crop & Tobacco & Tobacco & Tobacco & Tobacco \\
\hline Time of exposure & 30 years & 41 years & 38 years & 30 years \\
\hline Uses machinery & No & No & No & Yes \\
\hline $\begin{array}{l}\text { Wears personal } \\
\text { protective equipment }\end{array}$ & Yes & Yes & Yes & Yes \\
\hline $\begin{array}{l}\text { Equipment used in } \\
\text { application }\end{array}$ & Back sprayer & Back sprayer & Back sprayer & $\begin{array}{c}\text { Back sprayer Tractor } \\
\text { (seasonal) }\end{array}$ \\
\hline Other contacts & $\begin{array}{l}\text { Applying } \\
\text { Washing }\end{array}$ & $\begin{array}{c}\text { Preparing the product } \\
\text { Applying } \\
\text { Washing }\end{array}$ & $\begin{array}{c}\text { Preparing the product } \\
\text { Applying } \\
\text { Washing }\end{array}$ & $\begin{array}{c}\text { Preparing the product } \\
\text { Applying } \\
\text { Washing }\end{array}$ \\
\hline Pesticide & $\begin{array}{l}\text { Carbamate } \\
\text { Dithiocarbamate } \\
\text { Glyphosate } \\
\text { Organophosphate } \\
\text { Pyrethroid } \\
\text { Others }\end{array}$ & $\begin{array}{l}\text { Carbamate } \\
\text { Dinitroaniline } \\
\text { Dithiocarbamate } \\
\text { Glyphosate } \\
\text { Neonicotinoid } \\
\text { Organophosphate } \\
\text { Pyrethroid } \\
\text { Others }\end{array}$ & $\begin{array}{l}\text { Dithiocarbamate } \\
\text { Glyphosate } \\
\text { Neonicotinoid } \\
\text { Organophosphate } \\
\text { Pyrethroid } \\
\text { Others }\end{array}$ & $\begin{array}{c}\text { Dinitroaniline } \\
\text { Dithiocarbamate } \\
\text { Neonicotinoid } \\
\text { Organophosphate } \\
\text { Others }\end{array}$ \\
\hline
\end{tabular}

Source: The authors.

Figure 2. Data related to the work of pesticide-exposed tobacco growers

\begin{tabular}{|c|c|c|c|c|}
\hline General health & Case 1 & Case 2 & Case 3 & Case 4 \\
\hline Diseases in childhood & No & No & No & No \\
\hline Other chronic diseases & Yes & No & Yes & Yes \\
\hline $\begin{array}{l}\text { Neuropsychiatric } \\
\text { symptoms }\end{array}$ & No & $\begin{array}{c}\text { Yes } \\
\text { Minor neuropsychiatric } \\
\text { disorders }\end{array}$ & $\begin{array}{c}\text { Yes } \\
\text { Minor neuropsychiatric } \\
\text { disorders }\end{array}$ & $\begin{array}{c}\text { Yes } \\
\text { Minor neuropsychiatric } \\
\text { disorders }\end{array}$ \\
\hline Other symptoms & High blood pressure & No & $\begin{array}{l}\text { Blurred vision, memory } \\
\text { loss, anxiety }\end{array}$ & No \\
\hline SRQ-20 & Negative & Positive & Negative & Positive \\
\hline Use of medications & No & Yes & No & No \\
\hline Smoker & Yes & Yes & No & Yes \\
\hline Ex-smoker & No & No & Yes & No \\
\hline Alcoholism & Yes & No & No & No \\
\hline $\begin{array}{l}\text { Has already been } \\
\text { intoxicated by pesticide }\end{array}$ & Yes & Yes & Yes & Yes \\
\hline
\end{tabular}

Source: The authors. Legend: SRQ-20 = Self-Reporting Questionnaire, Brazilian version

Figure 3. Data related to the general health of pesticide-exposed tobacco growers 


\section{Audiological Assessment}

The data related to the auditory and neurovegetative symptoms are presented in Figure 4.
The data from both the basic and complementary audiological assessments are presented in Figure 5.

\begin{tabular}{|l|c|c|c|c|}
\hline Auditory Health & Case 1 & Case 2 & Case 3 & Case 4 \\
\hline Hears well & Yes & No & No & Yes \\
\hline Otalgia & No & No & No & No \\
\hline Tinnitus & Yes & No & Yes & No \\
\hline Noise discomfort & Yes & Yes & No & No \\
\hline Sensation of ear fullness & No & Yes & No & No \\
\hline Difficulty to comprehend & Yes & Yes & No & Yes \\
\hline Dizziness & No & Yes & Yes & Yes \\
\hline Headache & No & Yes & Yes & Yes \\
\hline Imbalance & No & Yes & No & Yes \\
\hline Exposure to intense sounds & No & No & No & Yes \\
\hline
\end{tabular}

Source: The authors.

Figure 4. Data related to the auditory and neurovegetative symptoms of pesticide-exposed tobacco growers

\begin{tabular}{|c|c|c|c|c|}
\hline Tests & Case 1 & Case 2 & Case 3 & Case 4 \\
\hline Pure-tone audiometry & $\begin{array}{c}\text { RE - RHL } 6 \text { and } 8 \mathrm{kHz} \\
\mathrm{LE}-\mathrm{SNHL} 4,6 \text { and } \\
8 \mathrm{kHz} \\
\text { Down-slope } \\
\text { configuration } \\
\text { Normal mean airway }\end{array}$ & $\begin{array}{l}\text { SNHL } 4,6 \text { and } 8 \mathrm{kHz} \\
\text { bilateral } \\
\text { Down-slope } \\
\text { configuration } \\
\text { Normal mean airway }\end{array}$ & $\begin{array}{l}\text { SNHL } 3,4 \text { and } 6 \mathrm{kHz} \\
\text { bilateral } \\
\text { Down-slope } \\
\text { configuration } \\
\text { Normal mean airway }\end{array}$ & $\begin{array}{c}\text { RE - SNHL 3, } 4 \\
\text { and } 6 \mathrm{kHz} \\
\mathrm{LE}-\mathrm{SNHL} 3,4,6 \\
\text { and } 8 \mathrm{kHz} \\
\text { Configuration: } \\
\text { notch RE and } \\
\text { down-slope LE } \\
\text { Normal mean airway }\end{array}$ \\
\hline Tympanometric curve & Type A bilateral & $\begin{array}{l}\text { RE - Type Ad } \\
\text { LE - Type A }\end{array}$ & Type A bilateral & Type A bilateral \\
\hline Acoustic reflex & $\begin{array}{l}\text { Present and normal } \\
\text { bilateral (IPSI and } \\
\text { CONTRA) } \\
\text { Recruiting suggested in } \\
4 \mathrm{kHz} \text { bilateral }\end{array}$ & $\begin{array}{c}\text { LE absent } \\
\text { (IPSI and CONTRA) } \\
\text { RE present, except for } \\
2 \mathrm{kHz} \text { (IPSI), and } \\
\text { present, except for } 2 \text { and } \\
4 \mathrm{kHz} \text { (CONTRA) }\end{array}$ & $\begin{array}{c}\text { Present and normal } \\
\text { Bilateral, except for } 4 \mathrm{kHz} \\
\text { RE (IPSI) and present } \\
\text { only in } 2 \mathrm{kHz} \text { bilateral } \\
\text { (CONTRA) }\end{array}$ & $\begin{array}{l}\text { Absent bilateral } \\
\text { (IPSI e CONTRA) }\end{array}$ \\
\hline BAEP & Normal & Normal & $\begin{array}{l}\text { Altered bilateral } \\
\text { Delay in V-wave }\end{array}$ & Normal \\
\hline
\end{tabular}

Legend: RE - right ear; LE - left ear; RHL - restricted hearing loss; SNHL - sensorineural hearing loss; IPSI - Ipsilateral acoustic reflex; CONTRA - Contralateral acoustic reflex; BAEP- Brainstem auditory evoked potentials.

Source: The authors.

Figure 5. Results of the audiological assessment (basic and complementary) of pesticide-exposed tobacco growers 


\section{DISCUSSION}

This case study presented four cases of tobacco growers exposed to pesticides, who presented a causal nexus between hearing loss and their occupation. The causal nexus was determined based on the work and health findings, and each case's auditory condition.

The authors suggest the need to look beyond the clinical approaches and consider the data related to each one's susceptibility and vulnerability, as well as their lifestyle, work and life conditions (production policies, work processes, and workers/employers' organization), socioeconomic, cultural and environmental situation in general ${ }^{9,12}$.

Figures 1,2, and 3, respectively, reveal the sample's profile that determined the nexus between work and health. It is highlighted that the sample comprised rural workers, in working age, though having begun working early in life, with low schooling, exposed to a variety of pesticides (including the organophosphates), and presenting health problems that could be related to pesticide exposure. These findings corroborate national studies that show similar profiles, in terms both of work ${ }^{13-17}$ and health ${ }^{15,17}$.

Some authors observed the simultaneous use of various substances in the procedures of working with pesticides; this fact was also reported by the tobacco growers interviewed in this study ${ }^{14}$ (Figure 2). The use of combined substances is widely discussed ${ }^{18,19}$, and it is emphasized here that the sum of various chemical substances can cause independent, synergic, and antagonistic effects on human health; moreover, different situations, as eating habits, drinking and smoking can interfere with the effects on health. Another study ${ }^{14}$ verified the use of more than 100 different pesticide formulations, referring that this frequently occurs without technical guidance.

Regarding the auditory and neurovegetative symptoms reported by the participants in this study, noise discomfort $(n=2)$, speech perception difficulties $(n=3)$, dizziness $(n=2)$, and imbalance $(n=2)$ stand out (Figure 4). These symptoms were essential to determine the nexus. The Health Vigilance Manual for Pesticide-Exposed Populations from the Pan American Health organization ${ }^{5}$ mentions the signs and symptoms related to pesticide intoxication, such as dizziness.

Studies indicate that pesticides, including the organophosphates, can modify the action of the efferent auditory system by inhibiting acetylcholinesterase, accumulating acetylcholine in the peripheral auditory system and sensory pathways. In the central auditory system, the accumulation of acetylcholine affects the transmission of action potentials from the efferent system of the superior olivary nucleus to the cochlea ${ }^{20}$. These alterations can damage the auditory and vestibular systems and be also associated with symptoms as tinnitus, dizziness, speech perception difficulties, and others. The authors recommend further studies on the auditory effects caused by the simultaneous use of various substances ${ }^{6,7}$.

Dizziness was reported by $35.7 \%$ and $72.25 \%$ of workers, respectively, in some pieces of research ${ }^{2,21}$. In another study, it was also diagnosed in $88.8 \%$ of agricultural workers and identified as of the irritative peripheral type ${ }^{22}$. Another symptom brought up was speech perception difficulty, present in $46 \%$ of the sample of exposed workers ${ }^{23}$. In other studies, besides dizziness, tinnitus (46\%) and speech perception difficulty $(29 \%)$ were also found ${ }^{24}$. In addition, headache (59.1\%), tinnitus $(27.3 \%)$, and imbalance $(22.7 \%)$ were found in this population ${ }^{25}$. Thus, it is pointed out that the action of neurotoxic chemical substances can affect both hearing and balance, which justifies the abovementioned complaints and findings among agricultural workers ${ }^{26}$.

When studying the effects on the central nervous system of workers exposed to multiple pesticides ${ }^{16}$, complaints of headache, fatigue, asthenia, vertigo, insomnia, anxiety, and irritability were found in $72.5 \%$ of the sample. Less frequently, complaints of tinnitus, nystagmus, mental confusion, blurred vision, convulsion, episodes of depression, and psychomotor excitement were also observed.

Concerning the ototoxicity in workers exposed to organophosphates, studies ${ }^{22}$ showed that all subjects in the research had dizziness. The authors suggested that this symptom be researched by the agents responsible for medical care, who work in the areas where there is agricultural activity nearby. They call attention to the fact that this occupation involves also the workers' family and that the literature reports about dizziness as a symptom of intoxication, with severe outcomes, interfering with both the capacity to work and the family and social quality of life.

Regarding the speech perception difficulties reported by the tobacco growers $(n=3)$, it is observed that the tritone mean value of the audiometric thresholds is normal in all cases, but a hearing loss in high frequencies could have contributed to such difficulty. Nevertheless, the hypothesis of alteration in the central auditory processing in cases of chronic pesticide 
intoxication must not be dismissed ${ }^{6,7,24}$. Authors ${ }^{27}$ report that complaints of speech perception difficulties incompatible with the audiometric findings - in the sense of pure-tone thresholds not showing sufficient hearing loss to justify such difficulties - should always be suspicious for auditory processing disorders. To validate this hypothesis, the central auditory processing test is recommended.

As for the audiological findings of the cases presented (Figure 5), the results show peripheral and central damage. Studies demonstrated that pesticide exposure contributes to damage in the peripheral and/ or central auditory and/or cognitive and/or vestibular system. This makes it necessary to apply complementary auditory tests when assessing pesticideexposed subjects, besides the tests normally used in basic audiological assessment ${ }^{8,16,22-24,27-35}$.

The pure-tone audiometry results revealed a sensorineural hearing loss in one or more high frequencies with a down-slope or notch configuration. Similar data were found in a study ${ }^{23}$ with tobacco growers, where the most affected frequencies in the pure-tone threshold audiometry were the high ones ( 3 to $6 \mathrm{kHz}$ ), whereas, in the high-frequency audiometry, they were the 9000 and $11200 \mathrm{~Hz}$ ones. In a study ${ }^{36}$, the audiometric tracing varied in the pesticide-exposed population, although with a greater incidence of down-slope audiometric curves. There were no cases with notch configuration, yet it should be mentioned that in the population studied there was no mention of noise exposure, only pesticide.

Regarding notch configuration, exposure to chemical products can, in certain cases, cause hearing loss with the same audiometric characteristics of the noise-induced hearing loss ${ }^{33}$; however, these findings cannot be generalized to all chemical products because the audiometric characteristics can change depending on the type of chemical product, as solvents, metals, carbon dioxide, pesticides, and others.

The tympanometry and acoustic reflex results revealed type A curves and presence of acoustic reflex in certain frequencies. On the other hand, there are studies $^{23}$ in which pesticide exposure is associated with the absence of acoustic reflex, as presented in case 4 . In the study with agricultural workers ${ }^{23}$, the absence of acoustic reflex was greater in the group of workers exposed to various types of pesticides when compared to the control group in various frequencies analyzed. Moreover, in another study ${ }^{36}$, there was a greater number of abnormal reflexes in the group of pesticide-exposed workers when compared to the nonexposed group.

The absence of acoustic reflex obtained in the cases assessed would not in itself indicate injury in the brainstem structures, given that peripheral hearing loss could influence reflex threshold ${ }^{23}$.

Concerning the BAEP, one participant presented absolute V-wave latency bilaterally, which could be associated with a diffuse impairment of the auditory pathways, both in the upper and lower brainstem ${ }^{18}$. The BAEP findings in this study corroborate other pieces of research conducted with pesticide-exposed populations ${ }^{18,37}$. A study ${ }^{18}$ demonstrated that the increase occurred in absolute V-wave latency in both ears. In contrast, in the studies by Jayasinghe and Pathirana $(2011)^{31}$, there was no difference in the BAEP records in pesticide-exposed populations in comparison with nonexposed populations. This subject calls for further investigations.

Given the above, pesticide exposure may have caused peripheral auditory damage in all four cases presented, and central damage in one of the cases.

In a study conducted with agricultural workers, researchers ${ }^{38}$ concluded that the population studied, despite directly working with pesticides, were unaware of auditory alterations associated with their use. The authors highlighted the need for actions to promote agricultural awareness of auditory risks and general health caused by their labor activities.

It is recommended that complete audiological assessments (both peripheral and central) be included for pesticide-exposed populations, as well as vestibular assessment (due to complaints of dizziness and/ or vertigo), to determine the causal nexus in workers exposed to pesticides. It is also necessary to notify the sanitary authorities (the SINAN, in Brazil) of the cases of hearing loss related to pesticides and refer them to the public health care (SUS) assistance ${ }^{9,10}$.

Moreover, attention is called to the importance of informative and educative actions on the part of health professionals, safety engineers, and others, besides the governmental health assistance and vigilance systems, to work together with the agricultural workers. These actions should encourage them to resort to protective equipment and use fewer amounts of pesticide or substitute them for equivalent, less toxic products in their activity. Equally important are the projects to develop planting techniques without the need for pesticides. Hence, agriculture professors should consider important issues as pesticides in their reflections, for 
them to contribute to a more comprehensive training of the future agricultural workers ${ }^{39,40}$.

\section{CONCLUSION}

This case study, according to the aspects considered and the criteria followed ${ }^{11}$, showed an association between both peripheral and central hearing loss and work in pesticide-exposed tobacco growers. Peripheral auditory damage was seen in the four cases, and central damage in one of them, demonstrating the need for complete audiological assessment of pesticide-exposed populations.

\section{REFERENCES}

1. BRASIL. Ministério da Saúde. Portaria GM n 1.378, de 09 de julho de 13. Regulamenta as responsabilidades e define diretrizes para execução e financiamento das ações de Vigilância em Saúde pela União, Estados, Distrito Federal e Municípios. In: Brasil. Ministério da Saúde. Sistema Nacional de Vigilância em Saúde e Sistema Nacional de Vigilância Sanitária. Brasília; 2014.

2. BRASIL. Ministério da Saúde. Portaria GM n 1.823 de 23 de agosto de 2012. Institui a Política Nacional de Saúde do Trabalhador e da Trabalhadora. In: Brasil. Ministério da Saúde. Política Nacional de Saúde do Trabalhador e da Trabalhadora. Brasília; 2013.

3. Pignatti WA, Lima FANS, Lara SS, Correa MLM, Barbosa JR, Leão LHC et al. Spatial distribution of pesticide use in Brazil: a strategy for Health Surveillance. Ciênc. saúde coletiva. 2017;22(10):3281-92.

4. BRASIL. Ministério da Saúde. Portaria GM n 204 de 17 de fevereiro de 2016. Define a lista nacional de notificação compulsória de doenças, agravos e eventos de saúde pública nos serviços de saúde públicos e privados em todo o território nacional, nos termos do anexo, e dá outras providências. In Brasil. In: Brasil. Ministério da Saúde. Sistema Nacional de Vigilância em Saúde. Brasília; 2017.

5. OPAS - Organização Pan-Americana de Saúde / OMS - Organização Mundial da Saúde. Manual de vigilância da saúde de populações expostas a agrotóxicos. Brasília, DF, 1996.

6. Kós MI, Hoshino AC, Asmus CIF, Mendonça R, Meyer A. Peripheral and central auditory effects of pesticide exposure: a systematic review. Cad Saude Publica. 2013;29(8):1491-506.
7. Gatto M, Fioretti M, Fabrizi G, Gherardi M, Strafella E, Santarelli L. Effects of potencial neurotoxic pesticides on hearing loss: a review. Neurotoxicology. 2014;42(1):24-32.

8. Sena TRR, Dourado SSF, Lima LV, Antoniolli AR. The hearing of rural workers exposed to noise and pesticides. Noise \& Health. 2018;20(92):23-6.

9. Paraná. Secretaria de Estado da Saúde. Superintendência de Vigilância em Saúde. Centro Estadual de Saúde do Trabalhador. Protocolo de avaliação das intoxicações crônicas por agrotóxicos. Curitiba: Sesa, 2013. (http://www. saude.pr.gov.br/arquivos/File/CEST/Protocolo_ AvaliacaolntoxicacaoAgrotoxicos.pdf)

10. Murakami Y, Pinto NF, Albuquerque GSC, Perna $P$, Lacerda A. Chronic pesticide poisoning in the tobacco farming. Saúde debate. 2017;41(113):563-76.

11. Conselho Federal de Medicina. Resolução CFM no 1.940/2010. Dispõe de normas específicas para médicos que atendam o trabalhador. In: Diário Oficial da União (D.O.U.) Brasília; Publicada no de 09 de fevereiro de 2010, seção I, p. 74.

12. Breilh J. Epidemiologia crítica: ciência emancipadora e interculturalidade. Rio de Janeiro: Fiocruz; 2006.

13. Cazé AMB, Lacerda ABM, Lüders D, Conto $\mathrm{J}$, Marques J, Leroux $\mathrm{T}$. Perception of the quality of life of tobacco growers exposed to pesticides: emphasis on health, hearing, and working conditions. Int Arch Otorhinolaryngol. 2019;23(1):50-9.

14. Moreira J, Jacob S, Peres F, Lima J, Meyer A, Silva $J$ et al. Avaliação Integrada do impacto do uso de agrotóxicos sobre a saúde humana em uma comunidade agrícola de Nova Friburgo, RJ. Ciênc. saúde coletiva. 2002;7(2):299-311.

15. Soares W, Almeida RM, Moro S. Trabalho rural e fatores de risco associados ao regime de uso de agrotóxicos em Minas Gerais. Cad Saude Publica. 2003;19(4):1117-27.

16. Sena TRR, Varga MM, Oliveira CCC. Hearing care and quality of life among workers exposed to pesticides. Ciênc. saúde coletiva. 2013;18(6):1753-61.

17. Araújo AJ, Lima JS, Moreira JC, Jacob SC, Soares MO, Monteiro MCM et al. Exposição múltipla a agrotóxicos e efeitos à saúde: estudo transversal em amostra de 102 trabalhadores 
rurais, Nova Friburgo, RJ. Ciênc. saúde coletiva. 2007;12(1):115-30.

18. Singh M, Minhas RS, Machhan P, Azad RK, Mohindroo S. Audiological assessment in organophosphorous poisoning. Int $\mathrm{J}$ Otorhinolaryngol Head Neck Surg. 2018;4(4):1-4.

19. Silva JM, Novato-Silva E, Faria HP, Pinheiro TMM. Agrotóxico e trabalho: uma combinação perigosa para a saúde do trabalhador rural. Ciênc. saúde coletiva. 2005;10(4):891-903.

20. Cáceres T, Megharaj M, Venkateswarlu K, Sethunathan N, Naidu R. Fenamiphos and related organophosphorus pesticides: Environmental fate and toxicology. Rev Environ Contam Toxicol. 2010;205:117-62.

21. Teixeira CF, Augusto LG, Morata T. Saúde auditiva de trabalhadores expostos a ruídos e inseticidas. Rev. Saúde Pública. 2003;37(4):417-23.

22. Hoshino AC, Pacheco-Ferreira H, Taguchi CK, Tomita S, Miranda MF. Estudo da ototoxicidade em trabalhadores expostos a organofosforados. Rev. bras. otorrinolaringol. 2008;74(6):912-8.

23. Lobato DCB. Disfunção auditiva induzida por agrotóxicos em trabalhadores agrícolas do Paraná [tese]. Curitiba (PR): Universidade Tuiuti do Paraná, Doutorado em Distúrbios da Comunicação; 2015.

24. França DMV, Lacerda ABM, Lobato D, Ribas A, Dias $K Z$, Leroux $T$ et al. Adverse effects of pesticides on central auditory functions in tobacco growers. Int. J. Audiol. 2017;56(4):233-41.

25. Körbes D, Silveira AF, Hyppolito MA, Munaro G. Ototoxicidade por organofosforado: descrição dos aspectos ultraestruturais do sistema vestibulococlear de cobaias. Braz. j. otorhinolaryngol. 2010;76(2):238-44.

26. Cóser MJS, Cioquetta E, Pedroso FS, Cóser PL. Potenciais auditivos evocados corticais em idosos com queixa de dificuldade de compreensão da fala. Arq. int. otorrinolaringol. 2007;11(4):396-401.

27. Dassanayake T, Gawarammana IB, Weerasinghe V, Dissanayake PS, Pragaash S, Dawson A. Auditory event-related potential changes in chronic occupational exposure to organophosphate pesticides. Clin Neurophysiol. 2009;120(9):1693-8.

28. Guida HL, Morini RG, Cardoso AV. Avaliação audiológica em trabalhadores expostos a ruído e praguicida. Braz. j. otorhinolaryngol. 2010;76(4):423-7.

29. Léonard MR. Effet de la co-exposition au bruit et aux pesticides organophosphorés sur l'audition des travailleurs agricoles [dissertação]. Montreal (Canada): Universidade de Montreal; 2011.

30. Camarinha CR, Frota S, Pacheco-Ferreira H, Lima MAT. Avaliação do processamento auditivo temporal em trabalhadores rurais expostos a agrotóxicos organofosforados. J Soc Bras Fonoaudiol. 2011;23(2):102-6.

31. Jayasinghe SS, Pathirana KD. Effects of deliberate ingestion of organophosphate or paraquat on brain stem auditory-evoked potentials. J Med Toxicol. 2011;7(4):277-80.

32. Bazílio MMM, Frota S, Chrisman JR, Meyer A, Asmus CIF, Camara VM. Processamento auditivo temporal de trabalhadores rurais expostos a agrotóxico. J. Soc. Bras. Fonoaudiol. 2012;24(2):174-80.

33. Morata TC, Lacerda ABM. Saúde auditiva. In: Zeigelboim BS, Jurkiewicz AL (orgs). Multidisciplinaridade na Otoneurologia. São Paulo: Roca; 2013. p. 386-99.

34. Alcarás PS, Lacerda ABM, Marques JM. Study of evoked otoacoustic emissions and suppression effect on workers exposed to pesticides and noise. CoDAS. 2013;25(6):527-33.

35. Delecrode CB. Processamento auditivo em trabalhadores expostos a ruído e inseticida: testes de ordenação temporal e P300 [dissertação]. Marília (SP): Distúrbios da Comunicação Humana, Universidade Estadual Paulista; 2014.

36. Tomiazzi JS, Pereira DR, Judai MA, Antunes PA, Favareto APA. Performance of machine-learning algorithms to pattern recognition and classification of hearing impairment in Brazilian farmers exposed to pesticide and/or cigarette smoke. Environ Sci Pollut Res Int. 2019;26(7):6481-91.

37. Singh M, Minhas RS, Machhan P, Azad RK, Mohindroo S. Audiological assessment in organophosphorous poisoning. Int $\mathrm{J}$ Otorhinolaryngol Head Neck Surg. 2018;4(4):966-9.

38. Stadler ST, Ribeiro VV, França DMVR. Self-perception of hearing disorders, habits, and hearing loss risk factors in farmers. Rev. CEFAC. 2016;18(6)1302-9.

39. Bedor CNG, Ramos LO, Pereira PJ, Rêgo MAV, Augusto LGS. Vulnerabilidade e situações de risco relacionados ao uso de agrotóxicos na fruticultura irrigada. Rev. bras. epidemiol. 2009;12(1):39-49.

40. Faria NXF, Rosa JAR, Facchini LA. Intoxicações por agrotóxicos entre trabalhadores rurais de fruticultura, Bento Gonçalves, RS. Rev. saúde pública. 2009;43(2):335-44. 